\title{
Questionnaire on body awareness of postural habits in young people: construction and validation
}

\author{
Questionário de percepção corporal dos hábitos \\ posturais de jovens: construção e validação
}

\author{
Debora Soccal Schwertner ${ }^{[a, b]}$, Raul Alexandre Nunes da Silva Oliveira ${ }^{[b]}$, Thais Silva Beltrame ${ }^{[a]}$, \\ Renata Capistrano $^{[\mathrm{a}]}$, Juliano Maestri Alexandre ${ }^{[\mathrm{a}]^{*}}$
}

[a] Universidade do Estado de Santa Catarina (UDESC), Florianópolis, SC, Brazil

[b] Universidade de Lisboa (UL), Lisbon, Portugal

\begin{abstract}
Introduction: The postural deviations associated with the changes in the habits of young people have increased over the last decades. Investigating the subject by way of a self-perception questionnaire allows one to understand the level of awareness the individual has concerning his/her postural habits. Objective: Designing a self-perception evaluation questionnaire about the postural habits of young people and to validate, pre-test, verify the reliability and the internal consistency of this instrument. Methods: The validity of the content was determined by 10 judges. The study involved young people (15 - 18 years old) from Florianopolis/Brazil. The questionnaire was pre-tested, applied to 15 youthful who provided qualitative information about it. The reproducibility was analyzed by way of a test-retest with 40 students, in a one-week gap, and was analyzed by interclass correlation coefficient. The internal consistency was analyzed by Cronbach's alpha with 679 students. A 5\% significance level was adopted. Results: Concerning to the validation of content, the questionnaire presented a total coefficient of 0.28 and $72 \%$ concordance was observed amongst the reviewers. The interclass correlation coefficient (test-retest) indicated acceptable
\end{abstract}

\footnotetext{
* DSS: MS, e-mail: debora.soccal@udesc.br RANSO: PhD, email: roliveira@fmh.ulisboa.pt TSB: PhD, e-mail: tsbeltrame@gmail.com RC: MS, e-mail: recapis@gmail.com

JMA: MS, e-mail: julianom.alexandre@gmail.com
} 
reproducibility values $(\mathrm{R}=0.66,0.74$ and $0.59 ; \mathrm{p}<0.001)$, with a decrease in the object-carrying dimension $(\mathrm{R}=0.32 ; \mathrm{p}=0.04)$. The questionnaire was considered suitable, quick and easy to fill in. The internal consistency presented a value of 0.80 . Conclusion: The questionnaire on body awareness of postural habits in young people is a valid instrument with good repeatability and reliability, its use can be recommended with teenagers showing the same profile as those used in this study.

Keywords: Adolescent. Posture. Reproducibility of Results. Surveys and Questionnaires.

\section{Resumo}

Introdução: Os desvios posturais associados às mudanças de hábitos em adolescentes vêm aumentando nas últimas décadas. Investigar por meio de questionário de autopercepção permite entender o nível de consciência que o indivíduo tem dos hábitos posturais. Objetivo: Construir um questionário de avaliação da autopercepção dos hábitos posturais de jovens, validar, pré-testar, verificar a confiabilidade e a consistência interna do instrumento. Métodos: A validade de conteúdo foi analisada por 10 juízes. $O$ estudo envolveu jovens (15 - 18 anos) de Florianópolis/Brasil. o questionário foi pré-testado, aplicado a 15 jovens que forneceram informações qualitativas sobre ele. A reprodutibilidade foi analisada através do teste-reteste com 40 alunos, em um intervalo de 1 semana, os dados foram analisados por meio do coeficiente de correlação intraclasse. A consistência interna foi analisada por meio do Alpha de Cronbach com 679 jovens. Adotou-se nível de significância de 5\%. Resultados: Na validação de conteúdo o questionário apresentou um coeficiente total de 0.28, observou-se uma concordância de $72 \%$ entre os avaliadores. O questionário foi considerado adequado, de rápido e fácil preenchimento. Os coeficientes de correlação intraclasse (teste-reteste) indicaram valores de reprodutibilidade aceitáveis $(R=0.66 ; 0.74$ e 0.59; $p<0,001)$, com baixa na dimensão carregando objetos ( $R=0.32 ; p=0.04)$. A consistência interna apresentou um valor de 0.80. Conclusão: $O$ questionário de percepção corporal dos hábitos posturais de jovens é um instrumento válido, com boa repetibilidade, confiabilidade e seu uso pode ser recomendado para adolescentes com o mesmo perfil deste estudo.

Palavras-chave: Adolescente. Postura. Reprodutibilidade dos Testes. Inquéritos e Questionários.

\section{Introduction}

Body perceptions are the first body experiences felt by a child, and more complex ways of body awareness continue to appear up to 16 or 17 years of age, when the great changes due to the puberty have already been restrained. The reduced body experiences in these life stages may compromise the sensory-motor experiences and internalize mental representations in the person that are out of phase with his/her own body, besides the low body organization [1].

The current life style, with its increased use of modern technologies, has determined modifications in people's behavior, making individuals more and more sedentary and with inappropriate body habits [2, 3]. If on one hand modernization has provided greater comfort and agility in work and leisure activities, on the other hand it has promoted a privation of body experiences [4]. A study carried out in Portugal verified that the sedentary time period tends to increase with age up to 16 to 17 years of age, at which point teenage boys maintain this behavior $70 \%$ of the day and teenage girls $71 \%$, then decreasing to approximately $66 \%$ of the day for adults [5]. Due to these sedentary activities, young people have passed the greater part of their time sitting down, since they combine long periods in this position during classes with the time spent at home in front of the computer playing video games and watching TV $[2,3,6]$. When an individual remains seated for an extensive time period, he/ she tends to adopt an inappropriate posture, relaxed and curved, leading to inappropriate postural habits and causing a series of postural compensations and complaints of discomfort and pain. There is an association between inappropriate postural habits and musculoskeletal 
disorders in teenagers [7] and many factors can corroborate with these body modifications such as the adjustments and adaptations to their own body changes, psychosocial demands [8], questions related to the excessive weight of school backpacks and their use in an asymmetric and inappropriate way $[7,9]$, and ergonomic difficulties [10,11].

The acquisition of adequate body behaviors and postural habits must be shaped during adolescence, minimizing postural disorders in adult life and their consequences [12]. Thus, the early detection of postural changes and musculoskeletal risks is essential for the application of a preventive and educational protocol [13].

Investigating by way of self-perception questionnaires allows one to understand the level of awareness that the individual has of the positions of the different body parts. With this instrument it is possible to identify postural asymmetry and deviations, although there may be differences between the individual awareness and the image observed by the researcher $[14,15]$. Self-perception instruments stimulate and evaluate the awareness of his/her body by the individual and might assist in the planning and evaluation of programs designed for postural/body education [16] and predict positive results. Body perception studies work with awareness and selfreeducation, making it possible for the individual to reflect on his/her way of life, think and feel, reactivating the sensory part of his/her being and allowing for new movements $[16,17]$.

Thus, the need to design a self-perception questionnaire for young people about body awareness and postural habits was verified. The objectives of this study were: 1 - to design a selfperception questionnaire to evaluate the postural habits of young people; 2 - to validate it; 3 - to pretest it; 4 - and to verify its reliability and internal consistency.

\section{Methods}

Three steps were carried out to analyze the psychometric properties of the instrument: a) content analysis (language clarity level, practical pertinence as analyzed by experts in the area); b) reproducibility; and c) internal consistency (HILL; HILL, 2012).
Ethical Aspects

The study was approved by Ethics in Research Committee of the Santa Catarina State University under the Process Number of CAAE (Submission Certificate for Ethical Assessment) 35004014.4.0000.0118/2014, approved on August 2,2014 . All the participants signed a term of consent which was also signed by those responsible for them. The patient's anonymity was preserved.

\section{Participants}

The study involved young people (15 - 18 years old) in their first or second year of high school at three schools in Florianopolis/Brazil. Students enrolled in both morning and afternoon periods were included, who were indicated by the directive team of the schools, accepted taking part in the study and had no cognitive, physical and/or psychiatric problems that could prevent them from filling in the questionnaire.

Fifteen students from school 1 took part in the instrument pretest stage; 40 young people from school 2 carried out the test-retest of the questionnaire in the reproducibility stage; and 679 young people from school 3 indicated the internal consistency of the questionnaire on filling it in.

Ten judges took part in the content validation process, nine of whom had graduated in physiotherapy and 1 in special education, with an average of 22.2 years of professional experience.

\section{Designing of the Questionnaire on Body Awareness of Postural Habits in Young People (Q-BAPHYP)}

The objective of this instrument was to identify the self-perception of young people concerning their postural habits in some environments (dimensions): in the classroom; at home during leisure activities (such as using the computer or something similar, watching TV) and resting; movements made during activities such as picking up objects from the floor, carrying/transporting backpacks and bags; body disciplining used by teachers in the classroom.

The final version of the self-perception questionnaire used language accessible to the age group and was clear and objective, consisting of 35 
closed questions (Likert items) divided into four dimensions for the perception of posture: in the classroom (11 questions), at home (17 questions), picking up objects (four questions) and related to the teacher's attitude in class (three questions). The average filling in time was seven minutes.

The answers for each item had 5 alternatives: never, rarely, often, always, don't know/don't remember. The Likert scale for this questionnaire was bipolar, starting at -2 for the positive assertive form (good postural habit), and at 2 for the negative assertive form. Numerical values were determined for each item and scores for each dimension, where positive values and scores suggest that the individual has an adequate perception of his/her body posture, and negative ones inappropriate postural habits. Answers with a value of zero indicate that the individual did not know how to answer or could not remember. In the dimensions, zero scores can result from both the sum of negative and positive answers (adequate and inappropriate body behaviors) and from answers with a value of zero (did not know or could not remember the answer).

The Q-BAPHYP was developed in 12 stages: 1 - literature review of the instruments used to evaluate the postural habits of young people; 2 - literature review to identify questionnaires on body self-perception and postural habits; 3 - field research carried out in two public schools in Florianopolis/Brazil; 4 - preparation of the first version; 5 - evaluation of the contents of the first version by experts in the area; 6 - preparation of the second version, incorporating suggestions made by the judges; 7 - presentation of the reviewed Q-BAPHYP to the judges; 8 - qualitative analysis by pretesting with young people; 9 - elaboration of the final version; 10 - test and re-test to verify reliability; 11 - verification of internal consistency using Cronbach's alpha; 12 - application to young people.

\section{Content validation procedure}

The questionnaire was presented to ten judges by a researcher, who was blinded to avoid influencing the answers.

The questionnaire contents were validated with respect to clarity, consistency and pertinence of the questions, as proposed by Hill and Hill [18].
Each evaluator assigned a score on a 1 to 5 gap scale (1 meaning that he/she agreed without reserve, 2 that he/she agreed with the generality but suggested changes, 3 that he/she did not agree with the way the item was formulated and suggested substantial changes to the way it was inserted in the questionnaire, 4 that he/she disagreed completely with the inclusion of the item and 5 no opinion).

Each evaluator was given a copy of the questionnaire, some observations (research objective, questionnaire objectives, literature review), a worksheet (containing the questions and blank spaces for notes and suggestions) and a brief questionnaire with six questions related to the instrument as a whole.

Based on the evaluations provided, the initial version of the questionnaire was changed and restructured to form the second version, which was resubmitted to the same experts.

\section{Pretesting and adaptation}

After the evaluation by the judges, the questionnaire was submitted to the evaluation/ pretest by the young people from school 1 with the objective of qualitatively identifying comprehension of the questions. After presenting the objectives of the study and the questionnaire to the teenagers, they received the questionnaire containing scores on a gap scale from 1 to 5 (as referred to before). There were also blank spaces between the questions for suggestions. For each group, after filling in the form (questionnaire with scores and suggestions), they were interviewed by a different researcher, not the one who handed out the questionnaires (to avoid influencing the replies). In this interview they were asked about any difficulties and their opinions about the instrument. The questionnaires were then collected, and the replies analyzed.

The questionnaire was presented to the groups that did not suggest any changes. The young people pointed out the lack of awareness of body perception in order to fill in the questionnaire since they had never paid attention to their own postural habits. This applied to all the questions of the questionnaire. The young people of the three groups found the questionnaire clear and interesting. 
Reproducibility and Internal consistency

For the reproducibility, forty students completed the form with questions related to their identification (date of birth, gender and profession) and received information about filling in the questionnaire and the objectives of the research. The interviewees were only told about the re-test procedure after finishing the initial test in order to minimize the opportunity to memorize their replies.

The re-test was applied by one researcher seven days after the first test, and analyzed by another researcher in order to avoid induction of the results.

For the internal consistency, the questionnaire was applied to 679 young people who did not report any problems in answering it.

\section{Statistical analysis}

The semantic analysis of the contents was carried out by way of the content validity coefficient proposed by Hernandez-Nieto [19]. On the other hand, the reproducibility was determined by way of the intraclass correlation coefficient (ICC) with a gap of seven days to observe the agreement between the measurements, and the internal consistency was analyzed by way of Cronbach's alpha. Values obtained for CVC $>0.7020$, for reproducibility $>0.5122$ and for internal consistency $>0.7023$ were considered adequate. The analysis was carried out using The Statistical Package for Social Sciences (SPSS), version 20.0, adopting a significance level of $5 \%$.

Intraclass correlation indexes above 0.50 are considered acceptable by the literature. Values between 0.50 and 0.69 are considered acceptable, from 0.70 to 0.79 good, from 0.80 to 0.89 very good and over 0.90 , excellent [20].

\section{Results}

\section{Characterization of the Sample}

Forty young people with an average age of 16.45 $(0.93)$ years took part in the reproducibility test. Of these young people, $60 \%$ of the girls and $77.5 \%$ of the boys did not work. In the internal consistency step, 679 teenagers filled in the Q-BAPHYP, having an average age of $16.23(0.89)$ years, where $62.7 \%$ of the young women and $81 \%$ of the young men did not work. Table 1 shows the values obtained for the reproducibility and internal consistency of the sample.

Table 1 -Sample characterization in the evaluation of reproducibility and internal consistency

\begin{tabular}{lll}
\hline Variables & Reproducibility & Internal Consistency \\
\hline Participants, $n$ & 40 & 679 \\
Age, years & $16.45(0.93)$ & $16.23(0.89)$ \\
Gender & & \\
$\quad$ Male & $16(40.0)$ & $253(37.3)$ \\
$\quad$ Female & $24(60.0)$ & $426(62.7)$ \\
Occupation & & \\
$\quad$ Yes & $9(22.5)$ & $129(19.0)$ \\
$\quad$ No & $31(77.5)$ & $555(81.0)$ \\
\hline
\end{tabular}

Note: Numerical values expressed as the mean plus standard deviation/ categorical values expressed as the frequency.

\section{Content validation procedure}

A first version of the questionnaire, constituted of 12 dimensions, was sent to the judges, presenting the average evaluation of the experts for the construct contents (Table 2).

Table 2 - Analysis of the content validation coefficient according to the judges

\begin{tabular}{lll}
\hline Dimensions of & \multicolumn{2}{l}{ Content validity } \\
\cline { 2 - 3 } body awareness & Mean (SD) & Content validity coefficient \\
\hline Classroom & $1.20(0.42)$ & $0.24(76 \%)$ \\
At home & $1.20(0.42)$ & $0.24(76 \%)$ \\
Carrying objects & $1.20(0.42)$ & $0.24(76 \%)$ \\
Teachers & $2.00(1.10)$ & $0.40(60 \%)$ \\
Total & - & $0.28(72 \%)$ \\
\hline
\end{tabular}

Note: SD - standard deviation.

The contents of the questionnaire were evaluated with respect to the clarity of the language and the practical pertinence. After corrections and suggestions, the instrument was changed to four dimensions and sent back to the same experts for the final version approval. The questionnaire was considered suitable and valid, with the average 
oscillating between one (agree without restrictions) and two (agree with the generality, but suggest changes). The content validity coefficient was calculated from the average of the evaluations. The instrument was shown to present a total content coefficient of 0.28 with concordance amongst the evaluators of $72 \%$.

The frequencies related to the general replies to the instrument can be seen in Table 3 .

The question referred to the objective of the instrument presented a higher percentage of "yes" replies, and the only question that presented "no" with a greater frequency referred to the structure of the replies. It must be pointed out that all the considerations and suggestions of the experts that checked "no" were reviewed and the instrument adjusted accordingly.

Table 3 -Evaluation by the experts of the instrument dimensions - first version

\begin{tabular}{lcc}
\hline Question & Yes & No \\
\hline $\begin{array}{l}\text { 1. Do you consider that all the questions are } \\
\text { formulated in a clear and objective way? }\end{array}$ & $60 \%$ & $40 \%$ \\
2. Do you consider that the language and the & & \\
terms used are adequate for the objectives & $70 \%$ & $30 \%$ \\
of the questionnaire for the population? & & \\
3. Do you think the questionnaire is structured \\
in a way to facilitate your comprehension & $10 \%$ & $90 \%$ \\
and replies? & & \\
$\begin{array}{l}\text { 4. Considering the time that you spent to read } \\
\text { and fill in the questionnaire, do you think this }\end{array}$ & $10 \%$ & $90 \%$ \\
instrument is adequate? & & \\
5. Do you think there is any significant & & \\
aspect that passed unnoticed or should be \\
changed? & $70 \%$ & $30 \%$ \\
$\begin{array}{l}\text { 6. Do you have any other suggestions that } \\
\text { could contribute to the improvement of this } \\
\text { questionnaire? }\end{array}$ & $50 \%$ & $50 \%$ \\
7. Do you think the questionnaire achieved the & & \\
objectives it was created for? & $90 \%$ & $10 \%$ \\
\hline
\end{tabular}

After the questionnaire approval by the judges and the test with the students, the instrument was considered valid and tested, containing 4 dimensions (awareness of postural habits in the classroom, at home, carrying objects and disciplinary orientations of the teachers) with 11,17 , four and three questions respectively, as shown in Table 4.
Table 4 - Questionnaire on body awareness and postural habits of young people and the respective values for the alternatives $(1=$ Never; $2=$ Rarely; $3=$ Frequently, 4 = Always, $5=$ Don't know/don't remember)

\begin{tabular}{|c|c|c|c|c|c|}
\hline Question/ dimension & 1 & 2 & 3 & 4 & 5 \\
\hline \multicolumn{6}{|l|}{$\begin{array}{l}\text { With respect to your body posture in } \\
\text { the CLASSROOM, do you: }\end{array}$} \\
\hline $\begin{array}{l}\text { Sit with your back well supported on } \\
\text { the backrest. }\end{array}$ & -2 & -1 & 1 & 2 & 0 \\
\hline Sit with your body tilted forward. & 2 & 1 & -1 & -2 & 0 \\
\hline $\begin{array}{l}\text { Sit with your upper body twisted (with } \\
\text { torso torsion). }\end{array}$ & 2 & 1 & -1 & -2 & 0 \\
\hline Sit with your buttocks slipping forward. & 2 & 1 & -1 & -2 & 0 \\
\hline $\begin{array}{l}\text { Sit with your buttocks well supported } \\
\text { without slipping forward. }\end{array}$ & -2 & -1 & 1 & 2 & 0 \\
\hline Sit with both feet firmly on the floor. & -2 & -1 & 1 & 2 & 0 \\
\hline Sit with your feet unsupported. & 2 & 1 & -1 & -2 & 0 \\
\hline Sit cross-legged. & 2 & 1 & -1 & -2 & 0 \\
\hline \multicolumn{6}{|l|}{ Score for sitting in the classroom } \\
\hline Stand with equal support on both legs. & -2 & -1 & 1 & 2 & 0 \\
\hline $\begin{array}{l}\text { Stand with more support on one leg. } \\
\text { Score for standing in the classroom }\end{array}$ & 2 & 1 & -1 & -2 & 0 \\
\hline $\begin{array}{l}\text { Carry out body movements (e.g.: joint } \\
\text { movements, stretching, etc.). }\end{array}$ & -2 & -1 & 1 & 2 & 0 \\
\hline $\begin{array}{l}\text { Score for movements in the } \\
\text { classroom }\end{array}$ & & & & & \\
\hline
\end{tabular}

\begin{tabular}{|c|c|c|c|c|c|}
\hline $\begin{array}{l}\text { With respect to your body posture at } \\
\text { HOME, do you: }\end{array}$ & & & & & \\
\hline $\begin{array}{l}\text { Sit with your back well supported on } \\
\text { the backrest. }\end{array}$ & -2 & -1 & 1 & 2 & 0 \\
\hline Sit with your body tilted forward. & 2 & 1 & -1 & -2 & 0 \\
\hline $\begin{array}{l}\text { Sit with your upper body twisted (with } \\
\text { torso torsion). }\end{array}$ & 2 & 1 & -1 & -2 & 0 \\
\hline Sit with both feet firmly on the floor. & -2 & -1 & 1 & 2 & 0 \\
\hline Sit with your feet unsupported. & 2 & 1 & -1 & -2 & 0 \\
\hline Sit cross-legged. & 2 & 1 & -1 & -2 & 0 \\
\hline $\begin{array}{l}\text { Sit with your buttocks well supported } \\
\text { without slipping forward. }\end{array}$ & -2 & -1 & 1 & 2 & 0 \\
\hline $\begin{array}{l}\text { Sit with your buttocks slipping forward. } \\
\text { Score for sitting at home }\end{array}$ & 2 & 1 & -1 & -2 & 0 \\
\hline Lie down (to sleep) on your stomach. & 2 & 1 & -1 & -2 & 0 \\
\hline Lie down (to sleep) on your side. & -2 & -1 & 1 & 2 & 0 \\
\hline $\begin{array}{l}\text { Lie down (to sleep) on your back. } \\
\text { Score for lying down at home }\end{array}$ & 2 & 1 & -1 & -2 & 0 \\
\hline
\end{tabular}

(To be continued) 
Table 4 - Questionnaire on body awareness and postural habits of young people and the respective values for the alternatives $(1=$ Never; $2=$ Rarely; $3=$ Frequently, $4=$ Always, $5=$ Don't know $/$ don't remember)

\begin{tabular}{|c|c|c|c|c|c|}
\hline Question/ dimension & 1 & 2 & 3 & 4 & 5 \\
\hline $\begin{array}{l}\text { Carry out body movements (e.g.: } \\
\text { joint movements, stretching, etc.). }\end{array}$ & -2 & -1 & 1 & 2 & 0 \\
\hline \multicolumn{6}{|l|}{ Score for movements at home } \\
\hline Stand with more support on one leg. & 2 & 1 & -1 & -2 & 0 \\
\hline $\begin{array}{l}\text { Stand with equal support on both } \\
\text { legs. }\end{array}$ & -2 & -1 & 1 & 2 & 0 \\
\hline \multicolumn{6}{|l|}{ Score for standing at home } \\
\hline $\begin{array}{l}\text { Watch TV or use the computer (tablet } \\
\text { or similar) sitting down with your } \\
\text { back well supported on the backrest. }\end{array}$ & -2 & -1 & 1 & 2 & 0 \\
\hline $\begin{array}{l}\text { Watch TV or use the computer lying } \\
\text { down. }\end{array}$ & 2 & 1 & -1 & -2 & 0 \\
\hline $\begin{array}{l}\text { Watch TV or use the computer sitting } \\
\text { down with your back curved and } \\
\text { your buttocks slipping forward. }\end{array}$ & 2 & 1 & -1 & -2 & 0 \\
\hline $\begin{array}{l}\text { Score for watching TV or using } \\
\text { the computer at home }\end{array}$ & & & & & \\
\hline \multicolumn{6}{|l|}{$\begin{array}{l}\text { With respect to CARRYING OBJECTS, } \\
\text { do you: }\end{array}$} \\
\hline $\begin{array}{l}\text { Carry your backpack/bag on one } \\
\text { shoulder (preferably on one side). }\end{array}$ & 2 & 1 & -1 & -2 & 0 \\
\hline $\begin{array}{l}\text { Carry your backpack/bag on both } \\
\text { shoulders }\end{array}$ & -2 & -1 & 1 & 2 & 0 \\
\hline $\begin{array}{l}\text { Score for carrying your } \\
\text { backpack }\end{array}$ & & & & & \\
\hline
\end{tabular}

(To be continued)
(Conclusion)

Table 4 - Questionnaire on body awareness and postural habits of young people and the respective values for the alternatives $(1=$ Never; $2=$ Rarely; $3=$ Frequently, $4=$ Always, $5=$ Don't know/don't remember)

\begin{tabular}{|c|c|c|c|c|c|}
\hline Question/ dimension & 1 & 2 & 3 & 4 & 5 \\
\hline $\begin{array}{l}\text { Bend your knees to pick up an object } \\
\text { from the floor }\end{array}$ & -2 & -1 & 1 & 2 & 0 \\
\hline $\begin{array}{l}\text { Bend your back to pick up an object } \\
\text { from the floor }\end{array}$ & 2 & 1 & -1 & -2 & 0 \\
\hline $\begin{array}{l}\text { Score for picking up an object } \\
\text { from the floor }\end{array}$ & & & & & \\
\hline \multicolumn{6}{|l|}{$\begin{array}{l}\text { In the classroom, do most of the } \\
\text { TEACHERS: }\end{array}$} \\
\hline $\begin{array}{l}\text { Ask the students to sit down and } \\
\text { remain silent. }\end{array}$ & 2 & 1 & -1 & -2 & 0 \\
\hline Allow the students movements. & -2 & -1 & 1 & 2 & 0 \\
\hline $\begin{array}{l}\text { Encourage the students to carry out } \\
\text { movements during the class. }\end{array}$ & -2 & -1 & 1 & 2 & 0 \\
\hline Score for the teachers & & & & & \\
\hline
\end{tabular}

\section{Reproducibility and Internal consistency}

The results of the analysis of reproducibility and internal consistency can be seen in Table 5 . The intraclass correlation coefficient (test-retest) indicated acceptable reproducibility values, with low correlation only found between the first and second evaluations in the carrying objects dimension. For the internal consistency analysis, the Cronbach's alpha presented a value of 0.80 .

Table 5 - Analysis of the intraclass correlation coefficient (ICC)

\begin{tabular}{|c|c|c|c|c|c|}
\hline \multirow{2}{*}{$\begin{array}{l}\text { Body awareness } \\
\text { dimensions }\end{array}$} & \multicolumn{4}{|c|}{ Intraclass correlation coefficient (ICC) } & \multirow[t]{2}{*}{ Cronbach's alpha } \\
\hline & $\mathbf{R}$ & Classification & IC $95 \%$ & $\mathrm{p}$-value & \\
\hline Classroom & 0.66 & Acceptable & $0.48-0.79$ & $<0.001$ & \\
\hline At home & 0.74 & Good & $0.61-0.84$ & $<0.001$ & \\
\hline Object carrying & 0.32 & Regular & $-0.41-0.60$ & 0.04 & \\
\hline Teachers & 0.59 & Acceptable & $0.36-0.76$ & $<0.001$ & \\
\hline Total & & & & & 0.80 \\
\hline
\end{tabular}

Note: p-value for the Intraclass correlation test.

\section{Discussion}

The evaluation of musculoskeletal problems and body behaviors depends on the choice of the investigation method, which, in turn, involves factors that go from implications of viability (cost, scope, environmental questions, number of subjects evaluated, team and professional qualification of the evaluators) to those of validity and reliability. The methods can be classified as: self-reports; 
observations by trained researchers; and measurements by monitoring equipment [21, 22]. Interviews (self-reports) have, as advantages over the other methods, the possibility of greater coverage in the observation of a larger number of data and dimensions of the same event, higher rate of success (related to the sample size), lower cost, and the fact that they are less susceptible to environmental interferences [23]. Self-report questionnaires about postural habits have been used in several studies, but in most of cases the objective of the instruments was to identify the acquisition of knowledge and analyze learning retention. In these questionnaires the questions are more directed at information and knowledge, than at awareness of the subject's own postural habits. Cardon et al. [23] used this kind of questionnaire in a study that investigated the effects of a 6-week postural education program in 9 - 11 years old Belgian children (participants $\mathrm{n}=347$ and control group $\mathrm{n}=359$ ). In addition to the self-perception questionnaire, the students were evaluated with respect to their sitting postural habit by way of kinematics. Low correlation was found between self-perception and the behavior observed amongst the young people, and despite the information retained, the participants of the intervention did not improve their self-effectiveness in relation to their back-care behavior [24]. Despite the low correlation between the image perceived and the image observed, questions leading the young people to an awareness of their own posture were chosen for the Q-BAPHYP. It is believed that when the young person replies to the questionnaire, he/she will become aware of his/her own postural habits, and involve himself/herself in a sensory experience that might serve as a contribution to a change in postural habits. The POSPER questionnaire, created by Ritter and Souza [16], was also developed based on the idea that body awareness could serve as a support for a change in postural habits. The instrument contents were validated and then applied to 59 students aged from 11 to 17 years old (average age 13.64). The reliability was verified (Pearson's correlation test showed a very high and significant intergroup correlation with $\mathrm{R}=0.91 ; \mathrm{p}<0.000$ ) and the internal consistency considered very good (Cronbach's alpha $=0.93$ ) and good (Cronbach's alpha $=0.88$ retest). In the same way as the Q-BAPHYP, the POSPER aims to identify the awareness of the young people with respect to their posture in the school dimension. It is composed of six questions, each with five possible answers, and there are four closed alternatives, but if the interviewee does not agree with these, he/ she can provide a better answer. Five of the six questions present choices through pictures (with the possibility of providing a written alternative, as explained previously) [16].

In the construction of the Q-BAPHYP, the use of the POSPER was tested in a group of five young people who reported difficulty in answering it because they noticed that their body posture was different from the alternatives in the pictures. In addition, the young people showed a series of postures used in their daily routines that were not shown by the instrument. Therefore, for the Q-BAPHYP, in order to better attend the needs of the group under study, an instrument based on closed questions was developed and other dimensions were added.

For the effectiveness of the construction of a questionnaire, Noll et al. [24] and Rubio et al. [25] recommend: 1 - carrying out field research and a broad literature review; 2 - selecting judges with experience in the research area and in teaching and research; 3 - all the judges must follow the same evaluation script, but at the same time they have the possibility to suggest and comment on the questions at will; 4 - the reformulated version or version in consensus must be approved by the judges; 5 - the quantitative and qualitative procedures must be used in the validation to evaluate each question; 6 - testing the questionnaire with a target group by way of a qualitative analysis of the answers to the questionnaire. The Q-BAPHYP followed all the recommendations, which contributed to the facility observed in answering the instrument with respect to clarity and pertinence. Although self-reporting instruments are subjective, they are conditioned to time and memory, and good reproducibility was reported in studies by Noll et al. [24], Candotti et al. [26] and Cardon et al. [27]. Noll et al. [24] developed the "Back Pain and Body Posture Evaluation Instrument (BackPEI)", which in addition to the awareness of postural habits evaluates the prevalence of back pain, demographic aspects, social-economics, and inherited and behavioral factors. The instrument was applied to 260 young people from 11 to 16 years old in a city in the south of Brazil, and was shown to have very good $(\mathrm{k}>0.8)$ or good $(0.6<\mathrm{k} \leq 0.8)$ reproducibility (as from 
the $\mathrm{k}$ - kappa coefficient), and $100 \%$ concordance (test and retest) for a question related to school material and lower reproducibility for the questions investigating the sitting posture (watching TV, using the computer or other activities). Candotti et al. [26] in a study with 58 young people aged between 7 and 16 (in a city in the south of Brazil), developed a questionnaire about body awareness especially to evaluate the way students transported their school material. The questionnaire contained four multiple choice questions with the first two questions presenting illustrated alternatives with photos. The test-retest was carried out with a group of 15 students who were not part of the sample. Using Spearman and Wilcoxon correlation tests it was shown that all the correlations were strong $(R \geq 0.94)$ and significant $(p \leq 0.01)$ and there were no significant differences $(p \geq 0.9)$ between the test-retest answers. Unlike the previous studies, in the Q-BAPHYP the interclass correlation coefficient (test-retest) indicated acceptable values for reproducibility, with low correlation only between the first and second evaluations in the carrying objects dimension. This lower level of reproducibility could express greater difficulty by the students in evaluating how they carried out this activity or that they changed their postural habits in this short period of time. In addition, it could be related to a lack of motivation or interest in responding to this specific question since both the individual awareness and the availability to answer are conditioned to these factors [28].

In the reliability evaluation, the period between the test-retest deserves methodological attention. A one-week gap is ideal since the young people will not remember the answers they gave in the first questionnaire and it is not sufficient time for significant changes to occur in their habits or behaviors $[18,24]$. Thus, in the present study the recommendation for a one-week gap between the test and retest was followed.

In the development of questionnaires, it is recommended the internal consistency of the instrument to be verified, identifying whether the answers vary due to the differences amongst the individuals or due to the questions used. Cronbach's alpha values below 0.7 show that the internal consistency of the scale used is low, the minimum acceptable value for alpha being 0.70 . Values for alpha between 0.80 and 0.90 are considered to be very good and the maximum value is 0.90 . Values above 0.90 indicate duplication and the redundant items should be eliminated [29]. Since the Q-BAPHYP obtained a Cronbach's alpha of 0.80 in the internal consistency analysis, this infers that the questionnaire is stable or, in other words, there is variation in the answers and no inconsistency in the questions used in the instrument.

Difficulties were observed in finding validated instruments in the same language and with the same concepts or contents, which prejudiced verification of the concurrent validity [30].

Some methodological care involves a prior explanation of the instrument to the young people. This study had some limitations: the responses were conditioned to memory, motivation, and selfperception. The self-perception of the postural habit may be different from the observed habit, and the measures of prevention and treatment should take this into consideration.

\section{Conclusion}

The Q-BAPHYP is a valid instrument with good repeatability and reliability. Its use can be recommended for application in studies with young people when the objectives are like those of the present study and related to self-awareness of postural habits in different contexts. Moreover, this questionnaire can be applied in schools and clinics since the language is accessible, it is easy to be answered and helps raise the factors associated with the complaint. The use of Q-BAPHYP can be recommended to be adapted in other languages/cultures, standardizing the data and providing subsidies for the prevention and treatment of inappropriate posture patterns and their consequences. The standardization allows comparing the results of different studies and analyzing the related factors such as culture and education rather than methodological differences.

The main contribution of this study was to fill in the gap in literature regarding instruments that allow the investigation of the awareness that young people possess of their postural habits in daily activities. We believe that the investigation of postural habits in a subjective way (self-perception) demonstrates the knowledge and self-care the individual has with his/her own body. 


\section{References}

1. Ribeiro PRL, Tavares MCGCF, Caetano AS. Contribuições de Fisher para a compreensão do desenvolvimento da percepção corporal. Psico-USF. 2012;17(3):379-86.

2. Ng SW, Popkin BM. Time use and physical activity: a shift away from movement across the globe. Obes Rev. 2012;13(8):659-80.

3. Owen N. Ambulatory monitoring and sedentary behaviour: a population-health perspective. Physiol Meas. 2012;33(11):1801-10.

4. Scarpato MT. Dança educativa: um fato em escolas de São Paulo. Cad CEDES. 2001;21(53):57-68.

5. Baptista F, Santos DA, Silva AM, Mota J, Santos R, Vale $\mathrm{S}$, et al. Prevalence of the Portuguese population attaining sufficient physical activity. Med Sci Sports Exerc. 2012;44(3):466-73.

6. American Academy of Pediatrics Council on Communications and Media. "Policy Statement: Children, Adolescents, and the Media. Pediatrics. 2013;132(5):958-61.

7. Minghelli B, Oliveira R, Nunes C. Postural habits and weight of backpacks of Portuguese adolescents: Are they associated with scoliosis and low back pain? Work. 2016;54(1):197-208.

8. Hasenbring MI, Chehadi O, Titze C, Kreddig N. Fear and anxiety in the transition from acute to chronic pain: there is evidence for endurance besides avoidance. Pain Manag. 2014;4(5):363-74.

9. Fonseca CD, Candotti CT, Noll M, Luz AMH, Santos ACD, Corso CO. Prevalence of back pain among high school students in a municipality in southern Brazil. Fisioter Mov. 2016;29(1):137-46.

10. Assunção A, Carnide F, Vieira F, Silva S, Araújo J. Mismatch of school furniture and back pain in adolescents with different maturation levels. Int J Hum Factors Ergon. 2013;2(1):66-81.

11. Lis AM, Black KM, Korn H, Nordin M. Association between sitting and occupational LBP. Eur Spine J. 2007;16(2):283-98.

12. Manchikanti L, Hirsch JA. What can be done about the increasing prevalence of low back pain and associated comorbid factors? Pain Manag. 2015;5(3):149-52.
13. Cardon G, De Clercq DLR, De Bourdeaudhuij IM, Breithecker D. Sitting habits in elementary schoolchildren: a traditional versus a "Moving school". Patient Educ Couns. 2004;54(2):133-42.

14. Branco LM, Hilário MOE, Cintra IP. Percepção e satisfação corporal em adolescentes e a relação com seu estado nutricional. Rev Psiquiatr Clin. 2006;33(6):292-6.

15. Damasceno VO, Vianna VRA, Vianna JM, Lacio M, Lima JR, Novaes JS. Imagem corporal e corpo ideal. R Bras Ci e Mov. 2006;14(2):87-96.

16. Ritter AL, Souza JL. Instrumento para conhecimento da Percepção de Alunos Sobre a Postura Adotada no Ambiente Escolar - Posper. Movimento. 2006;12(3):249-62.

17. Siemonsma PC, Stuive I, Roorda LD, Vollebregt JA, Walker MF, Lankhorst GJ, et al. Cognitive treatment of illness perceptions in patients with chronic low back pain: a randomized controlled trial. Phys Ther. 2013;93(4):435-48.

18. Hill MM, Hill A. Investigação por questionários. Lisboa: Edições Sílabo; 2012.

19. Hernandez-Nieto RA. Contributions to statistical analysis. Mérida: Universidad de Los Andes; 2002.

20. Field A. Descobrindo a estatística usando o SPSS. Porto Alegre: Artmed; 2009.

21. Spielholz P, Silverstein B, Morgan M, Checkoway $\mathrm{H}$, Kaufman J. Comparison of self-report, video observation and direct measurement methods for upper extremity musculoskeletal disorder physical risk factors. Ergonomics. 2001;44(6):588-613.

22. Trask C, Teschke K, Village J, Chow Y, Johnson P, Luong $\mathrm{N}$, et al. Measuring low back injury risk factors in challenging work environments: an evaluation of cost and feasibility. Am J Ind Med. 2007;50(9):687-96.

23. Cardon GM, De Clercq DLR, De Bourdeaudhuij IM. Back Education Efficacy in Elementary Schoolchildren. A 1-Year Follow-Up Study. Spine. 2002;27(3):299-305.

24. Noll M, Candotti CT, Vieira A, Loss JF. Back pain and body posture evaluation instrument (BackPEI): development, content validation and reproducibility. Int J Public Health. 2013;58(4):565-72. 
25. Rubio DM, Berg-Weger M, Tebb SS, Lee ES, Rauch S. Objectifying content validity: conducting a content validity study in social work research. Soc Work Res. 2003;27(2):94-104.

26. Candotti CT, Noll M, Roth E. Evaluation of weight and mode of transport of student in school of education. Rev Paul Pediatr. 2012;30(1):100-6.

27. Cardon G, De Clercq DLR, De Bourdeaudhuij IM. Effects of back care education in elementary schoolchildren. Acta Paediatr. 2000;89(8):1010-7.

28. Bejia I, Abid N, Bensalem K, Touzi M, Bergaoui N. Reproducibility of a low back pain questionnaire in Tunisian adolescents. Clin Rheumatol. 2006;25(5):715-20.
29. Streiner DL. Being inconsistent about consistency: when coefficient alpha does and doesn't matter. J Pers Assess. 2003;80(3):217-22.

30. Vanti C, Monticone M, Ceron D, Bonetti F, Piccarreta $\mathrm{R}, \mathrm{Guccione} \mathrm{AA}$, et al. Italian version of the physical therapy patient satisfaction questionnaire: crosscultural adaptation and psychometric properties. Phys Ther. 2013;93(7):911-22.

Received in $05 / 31 / 2017$

Recebido em 31/05/2017

Approved in 10/06/2017

Aprovado em 06/10/2017 